\title{
Aromatase promoter I.f is regulated by progesterone receptor in mouse hypothalamic neuronal cell lines
}

\author{
M Bertan Yilmaz ${ }^{1,2}$, Andrew Wolfe ${ }^{3}$, Hong Zhao', David C Brooks ${ }^{1}$ and Serdar E Bulun ${ }^{1}$ \\ ${ }^{1}$ Division of Reproductive Biology Research, Department of Obstetrics and Gynecology, Northwestern University Feinberg School of Medicine, \\ 303 E. Superior Street, Suite 4-123, Chicago, Illinois 60611, USA \\ ${ }^{2}$ Division of Medical Sciences, Department of Medical Biology and Genetics, School of Medicine, Cukurova University, Adana 01330, Turkey \\ ${ }^{3}$ Division of Endocrinology, Department of Pediatrics, Johns Hopkins University, Baltimore, Maryland 21287, USA \\ (Correspondence should be addressed to S E Bulun; Email: s-bulun @ northwestern.edu)
}

\begin{abstract}
Aromatase catalyzes the conversion of $\mathrm{C}_{19}$ steroids to estrogens. Aromatase and progesterone, both of which function at different steps of steroidogenesis, are crucial for the sexually dimorphic development of the fetal brain and the regulation of gonadotropin secretion and sexual interest in adults. The aromatase gene (Cyp19a1) is selectively expressed in distinct neurons of the mouse hypothalamus through a distal brain-specific promoter, I.f, located $\sim 40 \mathrm{~kb}$ upstream of the coding region. However, the regulation of aromatase expression in the brain is not well understood. In this study, we investigated a short feedback effect of progesterone analogues on aromatase mRNA expression and enzyme activity in estrogen receptor $\alpha$ (Esr1)-positive or -negative mouse embryonic hypothalamic neuronal cell lines that express aromatase via promoter I.f. In a hypothalamic neuronal cell line that highly expresses aromatase, progesterone receptor (Pgr), and Esr1, a progesterone agonist, R5020, inhibited aromatase mRNA level and enzyme activity. The inhibitory effect of R5020 was reversed by its antagonist, RU486. Deletion mutants of promoter I.f suggested that inhibition of aromatase expression by progesterone is conferred by the nt $-1000 /-500$ region, and R5020 enhanced binding of Pgr to the nt $-800 /-600$ region of promoter I.f. Small interfering RNA knockdown of Pgreliminated progesterone-dependent inhibition of aromatase mRNA and enzyme activity. Taken together, progesterone enhances recruitment of Pgr to specific regions of the promoter I.f of Cyp19a1 and regulates aromatase expression in hypothalamic neurons.
\end{abstract}

Journal of Molecular Endocrinology (2011) 47, 69-80

\section{Introduction}

Sex steroids influence most aspects of cellular organization and mammalian development. They play important roles in shaping neural functions and reproductive behavior throughout all stages of life. One of the major sex steroids is progesterone, which has a wide spectrum of functions in many organs, including the brain. Progesterone is primarily synthesized by the corpus luteum in females and by the testes and adrenal cortex in males, but it can also be locally synthesized by other tissues such as the brain (Keefe 2002, Wagner 2006).

Besides its well-established organizational and activational effects on reproductive neuroendocrine function and recovery after brain injury, progesterone also exerts a wide variety of actions on regions of the developing and adult brain that influence higher cognitive functions, pain mechanisms, fine motor skills, susceptibility to seizures, mood, temperature regulation, and sleep (Levine et al. 2001, Pluchino et al. 2006, Wagner 2006). Estrogen biosynthesis is dependent on the entry of cholesterol into mitochondria, followed by six enzymatic steps. Aromatase is the key enzyme that catalyzes the final step, the conversion of $\mathrm{C}_{19}$ steroids to biologically active estrogen, estradiol $\left(\mathrm{E}_{2}\right.$; Simpson \& Davis 2001, Bulun et al. 2005).

A single-copy gene (Cyp19a1) encodes aromatase, the inhibition of which effectively eliminates estrogen production in the entire body (Simpson \& Davis 2001). The mouse Cyp19a1 gene, which spans a $30 \mathrm{~kb}$ coding region and a $75 \mathrm{~kb}$ regulatory region $(\sim 105 \mathrm{~kb}$ in total length), is located on the long arm of chromosome 9 (Zhao et al. 2009). The downstream $30 \mathrm{~kb}$ coding region comprises nine coding exons (II-X; Golovine et al. 2003). The upstream $75 \mathrm{~kb}$ portion of the gene contains multiple promoters that direct transcription of alternative first exons, giving rise to aromatase mRNA species with unique $5^{\prime}$-untranslated regions (Chow et al. 2009). The upstream regulatory region contains two major promoters regulated in a tissue-specific manner: the proximal gonad-specific promoter and the distal brainspecific promoter, which lies $\sim 40 \mathrm{~kb}$ upstream of the ATG translational start site in coding exon II (Honda et al. 1996; http://www.ncbi.nlm.nih.gov/BLAST/).

In the vertebrate brain, aromatase is primarily expressed in the hypothalamus, hippocampus, and 
amygdala via a highly conserved promoter, I.f (Lephart 1997, Honda et al. 1999). Aromatase expression in the hypothalamus is primarily localized in the medial preoptic area and the ventromedial nucleus of the hypothalamus, which are the centers that govern reproductive functions of both sexes of different species (Lephart 1996, Sharma et al. 2004, Peterson et al. 2005, Voigt et al. 2007, Zhao et al. 2007).

The physiological roles of aromatase in the brain became obvious after examining mice with a disrupted aromatase gene (aromatase knockout (ArKO)) and men with inactivating mutations of the aromatase gene (Fisher et al. 1998, Jones et al. 2006). In both cases, aromatase deficiency was associated with increased testosterone and gonadotropin levels, indicating that aromatase and $\mathrm{E}_{2}$ were essential for regulating gonadotropin secretion. In addition, libido was significantly decreased in aromatase-deficient male mice and men and could be restored by $\mathrm{E}_{2}$ treatment, thus revealing essential roles for aromatase and $\mathrm{E}_{2}$ in regulating sexual behavior (Fisher et al. 1998, Bakker et al. 2004a,b, Simpson 2004b).

The signaling pathways or molecular mechanisms that regulate the brain-specific aromatase promoter I.f are not well understood. Several groups of investigators have found that protein kinases $\mathrm{A}$ and $\mathrm{C}$ and cAMP regulate aromatase expression and activity in the brain (Balthazart et al. 2001, Lavaque et al. 2006). Other groups showed that testosterone also upregulates aromatase mRNA and enzyme activity in the brain (Abdelgadir et al. 1994, Roselli et al. 1997, Negri-Cesi et al. 2001). Moreover, $\mathrm{E}_{2}$ was found to upregulate and downregulate hypothalamic aromatase mRNA and enzyme activity under both in vivo and in vitro circumstances (Iivonen et al. 2006, Zhao et al. 2007). However, progesterone has been thought to suppress aromatase mRNA levels and enzyme activity in some tissues (Fortune \& Vincent 1983) but induce it in others, implying that it may have divergent effects on aromatase (Lephart et al. 1998, Trainor et al. 2003, Pluchino et al. 2006, Wagner 2006). However, none of these studies provided a connection between aromatase expression and the regulation of promoter I.f in brain tissue. One group proposed that the transcription factor stress response element regulates the aromatase promoter via binding to its upstream region (Honda et al. 1999). Progesterone, a steroid hormone primarily secreted by the ovary and also locally synthesized in the brain, exerts its functions mostly via progesterone receptor (Pgr). Previously, progesterone has been proposed to regulate aromatase expression in the brain (Rhoda et al. 1987, Ing \& Tornesi 1997, Prange-Kiel et al. 2001). In this regard, we conducted this study to elucidate the mechanisms regulating hypothalamic aromatase activity by progesterone via the brain-specific aromatase promoter I.f in mouse hypothalamic neuronal cell lines.

\section{Materials and methods}

\section{Cell culture}

Mouse embryonic hypothalamic neuronal cell lines were purchased from Cellutions Biosystems, Inc. (Toronto, Canada) and were cultured in DMEM (Gibco) supplemented with $10 \%$ fetal bovine serum (FBS; Gibco) and $1 \%$ penicillin-streptomycin (Gibco) at $37^{\circ} \mathrm{C}$ in $95 \%$ air and $5 \% \mathrm{CO}_{2}$. The cells were studied at passages 15-16. After $24 \mathrm{~h}$ of serum starvation, cells were treated with various doses of the progesterone agonist, R5020 (Promegestone, Sigma-Aldrich), for varying lengths of time.

\section{RNA isolation and real-time RT-PCR}

Hypothalamic neurons were treated with either vehicle (ethanol) or $10^{-7}, 10^{-8}$, or $10^{-9} \mathrm{M}$ R5020, and total RNA was extracted after 6,12 , and $24 \mathrm{~h}$ of treatment using TRI reagent (Sigma) as per the manufacturer's instructions. On-column DNAse digestion was carried out using a DNAse I kit (Qiagen). The integrity of the isolated RNA was verified by running $5 \mu \mathrm{g}$ total RNA on a $1 \%$ formaldehyde gel. Total RNA $(5 \mu \mathrm{g})$ from vehicle, R5020 or progesterone antagonist, RU486 (mifepristone)-treated hypothalamic neurons was used for reverse transcription in a final volume of $20 \mu \mathrm{l}$ using the Superscript III First Strand RT synthesis kit (Invitrogen) according to the manufacturer's protocol. cDNA $(5 \mu \mathrm{l})$ was used for real-time PCR (the Taqman real-time primers and probe for aromatase were designed using ABI primer express Software 3.0) on an Applied Biosystems 7000 Sequence Detection System (Applied Biosystems, Foster City, CA, USA). The reactions were carried out using the ABI Taqman assay system for aromatase promoter I.f and power SYBR green for the aromatase coding region according to the manufacturer's protocol. The primers and probes used are as follows: Taqman assay primers for aromatase promoter I.f; forward 5'-AACTCACCATCTTCAAGAGTCCA- ${ }^{\prime}$, reverse 5'-GAGTGGCATGGCACTGACAGT-3'; probe 5'-AGGTCCGGTTTA-3'. Each contained a 6-carboxy-fluorescein phosphoramidite (FAM dye) label at the $5^{\prime}$-end and a minor groove binder and nonfluorescent quencher at the 3 -end and were designed to hybridize to the junction between promoter I.f and exon II. SYBR green assay primers for aromatase are as follows: forward $5^{\prime}$-TGTGTTGACCCTCATGAGACA-3', reverse 5'-CTTGACGGATCGTTCATACTTC-3'; for estrogen receptor $\alpha$ (Esrl): forward $5^{\prime}$-ATGAAAGGCGGCATACGGAAAG-3' ${ }^{\prime}$, reverse $5^{\prime}$-CACCCATTTCATTTCGGCCTTC-3'; and for glyceraldehyde-3-phosphate dehydrogenase (Gapdh): forward 5'-ACCACAGTCCATGCCATCAC-3' ${ }^{\prime}$, reverse 5'-TCCACCACCCTGTTGCTGTA-3'. 
In order to elucidate which $P g r$ isoform is predominantly expressed in hypothalamic neuronal cell lines, we amplified all three isoforms employing real-time PCR. For $P g r-B$ : forward 5'-GTGGAGGGCGCTTTCTCTG-3', reverse 5'-TCTGCCTCCCTCCCTATGAGT-3'; Pgr-AB: forward 5'-CTGGAGACCGAGGGCTCT$3^{\prime}$, reverse $5^{\prime}$-CCAGTGCTCGAGGTTTGCTC-3' ${ }^{\prime} P g r-A B C$ : forward $5^{\prime}$-GACACTGGCTGTGGAATTTCC-3', reverse $5^{\prime}$-CCAGGATCTTGGGCAACTG-3' ${ }^{\prime}$. Conventional PCR primers for Esr1: forward 5'-TCCTTCTAGACCCTTCAGTGAAGCC-3', reverse 5'-ACATGTCAAAGATCTCCACCATGCC-3'.

PCR was carried out in triplicate in a $50 \mu \mathrm{l}$ reaction volume using SYBR green PCR mix. The reactions were incubated at $50{ }^{\circ} \mathrm{C}$ for $2 \mathrm{~min}$ and $95^{\circ} \mathrm{C}$ for $10 \mathrm{~min}$, followed by 40 cycles of $95^{\circ} \mathrm{C}$ for $15 \mathrm{~s}$ and $60{ }^{\circ} \mathrm{C}$ for $1 \mathrm{~min}$. The threshold cycle $\left(C_{\mathrm{T}}\right)$ was defined as the fractional cycle number at which the fluorescence passes the fixed threshold. TaqMan $C_{\mathrm{T}}$ values were converted into absolute copy numbers. All RNA samples were normalized to the expression levels of Gapdh endogenous control. 'No template' and 'no RT' controls were used to ensure the absence of genomic DNA and reaction specificity. Totally, three independent experiments were performed to demonstrate reproducibility. Real-time RT-PCR product specificity was confirmed by melt curve analysis, gel electrophoresis, and product sequencing.

\section{Aromatase enzyme activity assay}

Aromatase enzyme activity within hypothalamic neurons was measured by a $\left[{ }^{3} \mathrm{H}\right]$ water release assay, which is used routinely in our laboratory (Shozu et al. 2003). In each well, $60 \mathrm{pmol}\left[{ }^{3} \mathrm{H}\right]$ androstenedione (PerkinElmer Life Sciences, Waltham, MA, USA) and 240 pmol cold androstenedione (Sigma) were added to $2 \mathrm{ml}$ serum-free DMEM covering hypothalamic neurons in culture dishes. In order to study the effect of R5020, hypothalamic neurons at $80-90 \%$ confluency were serum starved for $24 \mathrm{~h}$ and then treated with vehicle or R5020 for 6,12 , and $24 \mathrm{~h}$ at $37^{\circ} \mathrm{C}$ in $95 \%$ air and $5 \%$ $\mathrm{CO}_{2}$. Each treatment was performed in triplicate. A mixture of labeled and cold androstenedione was added to each well $4 \mathrm{~h}$ before the end of each time point and incubated until the completion of each treatment period. $\left[{ }^{3} \mathrm{H}\right]$ Androstenedione conversion to $\left[{ }^{3} \mathrm{H}\right] \mathrm{E}_{2}$ was stopped by adding $10 \%$ (weight/volume) trichloroacetic acid. Steroidal compounds containing unconverted $\left[{ }^{3} \mathrm{H}\right]$ androstenedione were removed from the mixture by first mixing with $4 \mathrm{ml}$ chloroform followed by centrifugation at $900 \mathrm{~g}$. The upper aqueous layer was removed and mixed with dextran-coated charcoal ( $1 \%$ weight/volume). Charcoal was precipitated by centrifugation. From each tube, $2 \mathrm{ml}$ clear solution was placed into a scintillation vial containing
$10 \mathrm{ml}$ scintillation fluid and counted in a scintillation counter (LS 6500, Beckman Coulter, Inc., Fullerton, CA, USA).

\section{Immunoblotting}

Hypothalamic neurons were cultured in $150 \mathrm{~mm}$ dishes in DMEM media containing 10\% FBS until reaching $80 \%$ confluency. Total protein was extracted from neurons using the M-PER mammalian protein extraction reagent (Pierce, Rockford, IL, USA). Protein concentration was determined using the BCA protein assay kit (Pierce). Cell lysate $(50 \mu \mathrm{g})$ was mixed with $2 \times$ Laemmli Sample Buffer (Bio-Rad Laboratories) and fractionated in $4-15 \%$ SDS-PAGE. Proteins from the gel were transferred to a nitrocellulose membrane. The membranes were then incubated with anti-Esr1 or antiPgr antibody (1:1000 dilution; Upstate, Charlottesville, VA, USA) in $5 \%$ milk solution overnight at $4{ }^{\circ} \mathrm{C}$. The membrane was washed for $30 \mathrm{~min}$ and then incubated with anti-rabbit IgG-peroxidase conjugate (Upstate) as a secondary antibody (1:3000 dilution). Incubation with the secondary antibody was performed at room temperature for $1 \mathrm{~h}$. The signal was detected using SuperSignal West Femto maximum sensitivity substrate chemiluminescence kit (Pierce) according to the manufacturer's instructions followed by exposure to BioMax ML X-ray film (Eastman Kodak) for 1-5 min. Then, the membranes were stripped of the first antibody and probed with anti-actin followed by the same signal detection procedure.

\section{Transient transfection and luciferase assays}

Transient transfection of N42 hypothalamic neurons was carried out in 12-well plates with Fugene HD transfection reagent (Roche Diagnostics) with the following plasmids: 1) $1 \mu \mathrm{g}$ pGL3-basic luciferase reporter plasmid containing the promoter I.f nt $-1000 /-1$ fragment or progressively truncated promoter I.f fragments $(-700,-500,-200$, and -50) and 2) $50 \mathrm{ng}$ pRL-TK plasmid as an internal control (Promega). Neurons were serum deprived 1 day before transfection. After $24 \mathrm{~h}$ of transfection, N42 hypothalamic neurons were treated either with vehicle (ethanol) or with $10^{-7}$ M R5020 for $24 \mathrm{~h}$. At the end of the treatment period, transfected neurons were washed twice in PBS and lysed in $250 \mu \mathrm{l}$ lysis buffer $(0 \cdot 1 \mathrm{M}$

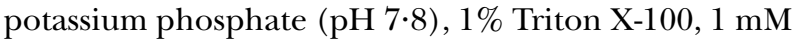
dithiothreitol, and $2 \mathrm{mM}$ EDTA). Luciferase assays were performed with $20 \mu \mathrm{l}$ cell lysate employing a DualLuciferase Reporter Assay System kit (Promega). Luminescence was measured with a LUMAT LB9507 luminometer (EG\&G Berthold, Bad Wildbad, Germany). Results are presented as the average of 
luciferase activity from triplicate experiments and expressed as the ratio to the internal standard Renilla luciferase. Plasmids used in transfection experiments were purified using an EndoFree Plasmid Isolation Kit (Qiagen), and their purity was verified by spectrophotometry and agarose gel electrophoresis. All transfection assays were performed using equimolar amounts of plasmids.

\section{Chromatin immunoprecipitation assay}

Chromatin immunoprecipitation (ChIP) assays were performed with the Acetyl-Histone H4 Immunoprecipitation Assay Kit (Upstate) following the manufacturer's instructions with minor modifications. Briefly, after reaching $80-90 \%$ confluency in $150 \mathrm{~mm}$ culture dishes $\left(\sim 2 \times 10^{7}\right.$ cells $)$, hypothalamic neurons were serum starved for $24 \mathrm{~h}$, then treated with either vehicle (ethanol) or $10^{-7}$ M R5020 for $6 \mathrm{~h}$. Neurons were then cross-linked with $1 \%$ formaldehyde for $10 \mathrm{~min}$ at room temperature on an orbital shaker followed by the addition of $1 \mathrm{M}$ glycine for $5 \mathrm{~min}$. Neurons were washed with cold PBS containing protease inhibitors and were lysed using a lysis buffer (50 mM Tris- $\mathrm{HCl}, \mathrm{pH} 8 \cdot 1$, containing $1 \%$ SDS and $10 \mathrm{mM}$ EDTA). The cells were sheared using a Sonic Dismembrator Model 100 (Fisher Scientific, Hampton, NH, USA) at $70 \%$ maximum amplitude ( $15 \mathrm{~s}$ on, $60 \mathrm{~s}$ off) for five pulses to obtain DNA fragments in the range of 200-1000 bp. The sonicated cell supernatant was diluted tenfold in ChIP dilution buffer and $40 \mu \mathrm{l}$ was used as input DNA (positive control). Pre-cleared chromatin was used for immunoprecipitation reactions with $5 \mu \mathrm{g}$ of the Pgr antibody or nonspecific (NS) rabbit IgG (Upstate). The reactions were incubated on a rotator overnight at $4{ }^{\circ} \mathrm{C}$. The immune complexes were collected using protein A-agarose/DNA beads and washed five times using low salt, high salt, and lithium chloride and twice with Tris-EDTA buffers. The absorbed immune complexes were recovered by incubation with elution buffer $(1 \%$ SDS and $0 \cdot 1 \mathrm{M} \mathrm{NaHCO}_{3}$ ). Part of the eluate was saved and checked for targeted protein immunoprecipitation by immunoblotting. After reverse cross-linking at $65^{\circ} \mathrm{C}$ for $4 \mathrm{~h}$, the genomic DNA was purified using a DNA purification kit (Qiagen). The promoter I.f region was scanned for Pgr recruitment by PCR amplification using seven different pairs of primer sets representing the nt $-1000 /-1$ region in $\sim 150$ bp intervals. PCRs were optimized according to each primer set, with the best amplification conditions for all primer sets being the following: 35 cycles $(30 \mathrm{~s}$ denaturation at $94{ }^{\circ} \mathrm{C}, 1 \mathrm{~min}$ annealing at $57.5^{\circ} \mathrm{C}$, and $1 \mathrm{~min}$ elongation at $\left.72^{\circ} \mathrm{C}\right)$. ChIP primers were designed using the Primer3 Software (http://frodo.wi.mit.edu/ primer3/input.htm) and were as follows: forward 5'-GGCTTCTCTTGGTACGCTGA-3' ${ }^{\prime}$ and reverse
5'-TTGTTGCTAAGAGATCAGTTGCTT-3' ${ }^{\prime}$, which amplified the $n t-190 /-40$ region of promoter I.f to yield a 150 bp amplicon; forward 5'-ACCACAGAGAGTGAAAGTTTGAG-3' $3^{\prime}$ and reverse 5'-GCGTACCAAGAGAAGCCAAT-3', which amplified the nt $-334 /-173$ region of promoter I.f to yield a $162 \mathrm{bp}$ amplicon; forward $5^{\prime}$-GCATTCAAGTTTGCTCAGAGG-3 ${ }^{\prime}$ and reverse $5^{\prime}$-TTCTTTTGATGGGGTTGCAC-3', which amplified the nt $-431 /-281$ region of promoter I.f to yield a 151 bp amplicon; forward 5'-CCTGCCTAAAGGCTAAGATCC-3' ${ }^{\prime}$ and reverse $5^{\prime}$-ACACACATACACCTCTGAGCAAA-3', which amplified the nt $-549 /-399$ region of promoter I.f to yield a $151 \mathrm{bp}$ amplicon; forward $5^{\prime}$-CCCAAACCTTATCAACTTAGCC-3' ${ }^{\prime}$ and reverse 5'-GGATCTTAGCCTTTAGGCAGGT-3', which amplified the $n t-692 /-528$ region of promoter I.f to yield a $165 \mathrm{bp}$ amplicon; forward $5^{\prime}$-TGAGATGTAAACATTATGTGTGTGCT- $3^{\prime}$ and reverse $5^{\prime}$-GGTTTGGGTTTAGGGGAAT-3' ${ }^{\prime}$, which amplified the nt $-793 /-685$ region of promoter I.f to yield a $109 \mathrm{bp}$ amplicon; and forward $5^{\prime}$-AGCAGAGATGGCTTGTGGTT- $3^{\prime}$ and reverse 5'-GCACACACATAATGTTTACATCTCA-3', which amplified the nt $-925 /-768$ region of promoter I.f to yield a $158 \mathrm{bp}$ amplicon. All ChIP buffers used in this protocol contained a 1x protease inhibitor cocktail (Sigma).

\section{Small interfering RNA}

NS small interfering RNA (siRNA) and Pgr siRNA were purchased from Dharmacon (Chicago, IL, USA). Pgr knockdown was verified by real-time RT-PCR and immunoblotting. Before 1 day of transfection, hypothalamic neurons were plated in 6-well plates to achieve $50 \%$ confluency at the time of transfection and were then transfected with $100 \mathrm{nM}$ NS siRNA or Pgr siRNA in triplicate using Lipofectamine RNAiMAX reagent (Invitrogen Life Technologies, Inc.) according to the manufacturer's protocol. After $48 \mathrm{~h}$ of transfection, neurons were serum-starved for $24 \mathrm{~h}$, followed by treatment with $10^{-7}$ M R5020 for $6 \mathrm{~h}$. Total mRNA was extracted for real-time RT-PCR assay, and total protein was isolated using M-PER reagent for immunoblot analysis.

\section{Statistical analysis}

Statistical analyses were performed by Welch's paired $t$ test and one-way analysis of variance followed by a Tukey multiple comparisons test using the StatView 5.0 Statistical Software package (SAS Institute, Cary, NC, USA). Significance was determined at $\alpha=0 \cdot 05$ and $\beta=0 \cdot 20$. The values for mRNA and aromatase activity were provided as mean \pm s.E.M. 


\section{Results}

\section{Aromatase, Esr1, and Pgr expression levels in hypothalamic neuronal cell lines}

To verify estrogen production and estrogen and progesterone responsiveness of the study cell lines, conventional RT-PCR, real-time RT-PCR, and immunoblot analyses were performed to measure aromatase, Esr1, and Pgr mRNA or protein in N38 and N42 hypothalamic neurons. Promoter I.f-driven aromatase expression (Fig. 1A), Pgr expression (Fig. 1B and C), and Esr1 expression (Fig. 1D and E) were lower in N38 hypothalamic neurons compared with N42 hypothalamic neurons. These results were reproducibly observed in three independent experiments.

\section{Effect of the progesterone agonist, R5020, on aromatase mRNA expression and enzyme activity in N38 and N42 cell lines}

Real-time RT-PCR and aromatase enzyme activity assays were performed to determine whether the progesterone agonist R5020 had an effect on aromatase mRNA expression and enzyme activity. We treated N38 and N42 hypothalamic neurons with $10^{-7}$ M R5020 for 6, 12, and $24 \mathrm{~h}$. We observed that R5020 suppressed aromatase mRNA expression (Fig. 2A) and enzyme activity (Fig. 2B) at the $6 \mathrm{~h}$ time point but not at other time points in N42 hypothalamic neurons. However, aromatase RNA expression and enzyme activity at the $6 \mathrm{~h}$ time point in N38 hypothalamic neurons were induced by R5020 treatment (data not shown). Aromatase enzyme activity in each neuronal line treated with the aromatase enzyme inhibitor letrozole (LET) was undetectable.

The progesterone antagonist, RU486, inhibits R5020-dependent suppression of aromatase mRNA expression and enzyme activity in N42 hypothalamic neuronal cell lines

To clarify whether the effect of R5020 on aromatase mRNA expression and enzyme activity was Pgr dependent, we treated N42 hypothalamic neurons with the progesterone antagonist, RU486 (mifepristone). RU486 inhibited R5020-dependent suppression of aromatase mRNA expression and enzyme activity as assessed by real-time RT-PCR and aromatase enzyme activity assays (Fig. 3A and B). Aromatase activity in N42 neuronal line treated with the aromatase enzyme inhibitor LET was undetectable.

\section{The nt $-1000 /-500$ region of aromatase promoter I.f confers responsiveness to a progestin}

To identify progestin-responsive cis-regulatory elements within the $\mathrm{nt}-1000 /-1$ region of aromatase
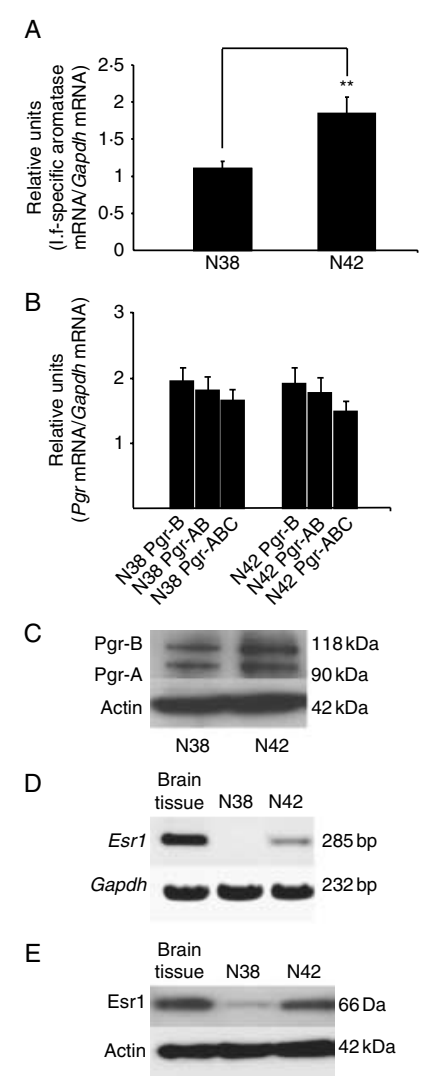

Figure 1 Promoter I.f-driven aromatase expression and Pgr and Esr1 expression in N38 and N42 hypothalamic neurons. (A) Realtime RT-PCR was performed with a probe complementary to the promoter I.f to exon II junction to measure promoter I.f-driven aromatase mRNA expression. Relative units are shown as the ratio of aromatase mRNA to Gapdh mRNA. Results are expressed as mean \pm S.E.M. of three independent experiments ( ${ }^{* \star} P<0 \cdot 01$, paired $t$ test). (B) Conventional RT-PCR and (C) immunoblotting were performed to measure Pgr expression in brain tissue (positive control) and N38 or N42 hypothalamic neurons. (D) Conventional RT-PCR and (E) immunoblotting were performed to measure Esr1 expression in brain tissue (positive control) and N38 or N42 hypothalamic neurons. Gapdh and actin were used as loading controls. Figures represent one of the three independently performed experiments.

promoter I.f, we generated a series of truncated reporter constructs and transiently transfected them into N38 and N42 hypothalamic neurons. In N42 hypothalamic neurons, the nt $-1000 /-1$ and the $\mathrm{nt}$ $-700 /-1$ promoter-luciferase reporter constructs were responsive to R5020 (threefold repression; Fig. 4).

\section{Pgr interacts with aromatase promoter l.f}

We performed ChIP assays to demonstrate that Pgr is recruited to aromatase promoter I.f in N42 hypothalamic neurons. We used seven different sets of overlapping primer pairs representing the $\mathrm{nt}$ $-1000 /-1$ region of promoter I.f in $\sim 150 \mathrm{bp}$ 

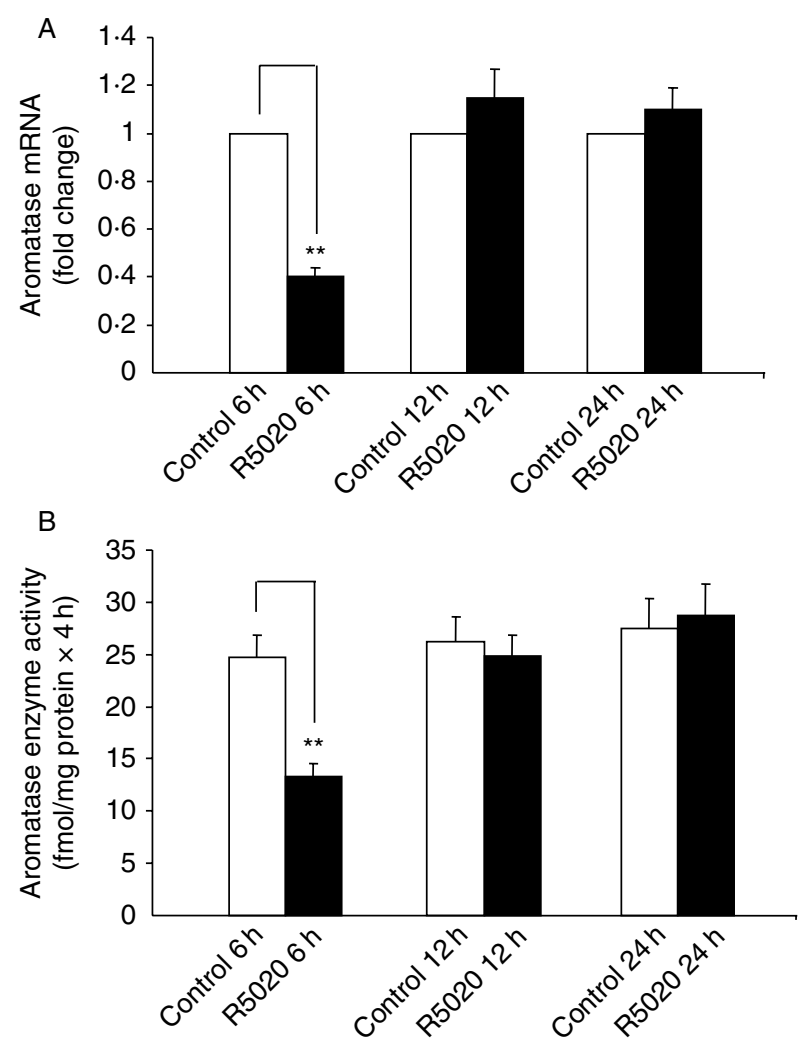

Figure 2 The progesterone agonist, R5020, regulates aromatase mRNA expression and enzyme activity in N42, but not N38, hypothalamic neurons. (A) Real-time RT-PCR was performed to measure aromatase mRNA expression after 6,12 , and $24 \mathrm{~h}$ of R5020 $\left(10^{-7} \mathrm{M}\right)$ treatment. Aromatase mRNA levels were normalized to Gapdh mRNA levels. Results are expressed as mean \pm S.E.M. from three independent experiments $\left({ }^{\star \star} P<0.01\right.$, paired $t$ test). Aromatase activity assays were performed in (B) N42 hypothalamic neurons after 6, 12, and $24 \mathrm{~h}$ of R5020 $\left(10^{-7} \mathrm{M}\right)$ treatment. The results are expressed as mean \pm S.E.M. from three independent experiments $\left({ }^{\star \star} P<0 \cdot 01\right.$, paired $t$ test).

intervals. The most consistent and intense Pgr recruitment occurred in the $\mathrm{nt}-800 /-600$ region (Fig. 5A). Under serum-starved conditions, we did not observe Pgr recruitment to the nt $-800 /-600$ region of promoter I.f in N42 hypothalamic neurons; however, recruitment to this region was enhanced by R5020 treatment $\left(10^{-7} \mathrm{M}, 6\right.$ h; Fig. 5B). We applied densitometry to PCR gels to calculate fold enrichment as a ratio of recruitment of Pgr antibody-bound chromatin to that of nonspecific IgG-bound chromatin. We demonstrated that R5020 induced recruitment of Pgr by $2 \cdot 1$ fold to this progestin-responsive region (Fig. 5B).

\section{Pgr mediates R5020-dependent suppression of aromatase mRNA expression and enzyme activity}

siRNA was used to determine whether endogenous Pgr in N42 hypothalamic neurons mediates R5020-dependent suppression of aromatase mRNA expression and enzyme activity. As shown in Fig. 6A and B, siRNA knockdown of $P g r$ in N42 hypothalamic neurons abolished suppression of aromatase mRNA levels and enzyme activity by R5020 $\left(10^{-7} \mathrm{M}\right)$ treatment. The knockdown of Pgr was confirmed by real-time RT-PCR and immunoblotting (Fig. 6C and D).

\section{Relative Pgr and Esr1 expression is critical for $E_{2^{-}}$and progestin-dependent regulation of aromatase mRNA expression and enzyme activity}

We have previously shown that $\mathrm{E}_{2}$ induces aromatase mRNA expression and enzyme activity in N42 but not in N38 hypothalamic neurons, which express lower Esr1 and Pgr levels compared with N42 hypothalamic neurons (Fig. 1C and D). To determine whether different levels of Esr1 or Pgr expression affect estrogen or progestin regulation of aromatase mRNA levels and enzyme activity, we treated N38 and N42 hypothalamic neurons with $10^{-7} \mathrm{M} \mathrm{R} 5020,10^{-7} \mathrm{M} \mathrm{E}_{2}$, or both for $6 \mathrm{~h}$. R5020 treatment induced aromatase mRNA expression (Fig. 7A) and enzyme activity (Fig. 7B) in N38 hypothalamic neurons, but suppressed them in N42 hypothalamic neurons. In addition, $\mathrm{E}_{2}$ treatment did not change aromatase mRNA expression and enzyme activity in N38 hypothalamic neurons but induced both
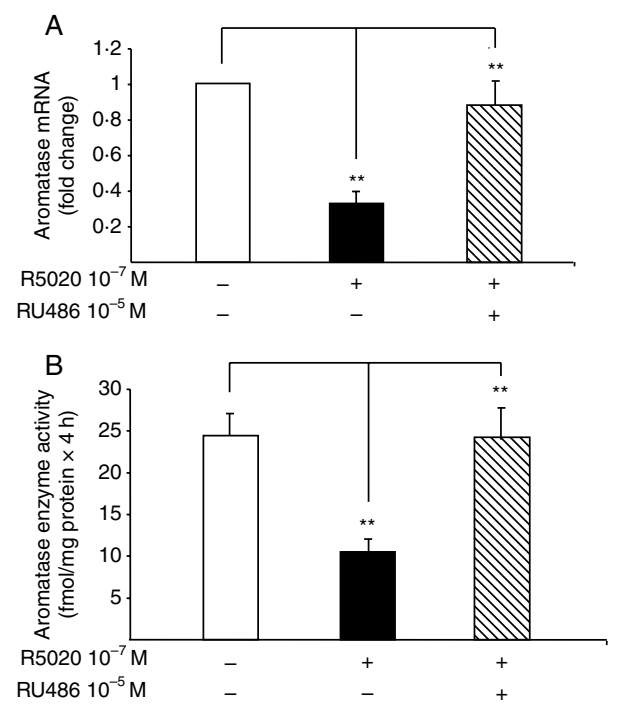

Figure 3 The progesterone antagonist, RU486, reverses R5020dependent suppression of aromatase mRNA expression and enzyme activity in N42 hypothalamic neurons. (A) Real-time RT-PCR was performed in the presence or absence of $10^{-7} \mathrm{M}$ R5020 plus or minus $10^{-5} \mathrm{M}$ RU486 for $6 \mathrm{~h}$. Aromatase mRNA levels were normalized to Gapdh mRNA levels. The results are expressed as mean \pm S.E.M. from three independent experiments $\left({ }^{\star *} P<0 \cdot 01\right.$, ANOVA). (B) Aromatase activity assays were performed to measure enzyme activity in the presence or absence of $10^{-7} \mathrm{M} \mathrm{R} 5020$ plus or minus $10^{-5} \mathrm{M} \mathrm{RU} 486$ for $6 \mathrm{~h}$. The results are expressed as mean \pm S.E.M. $\left(n=3 ;{ }^{\star \star} P<0 \cdot 01\right.$, ANOVA $)$. 


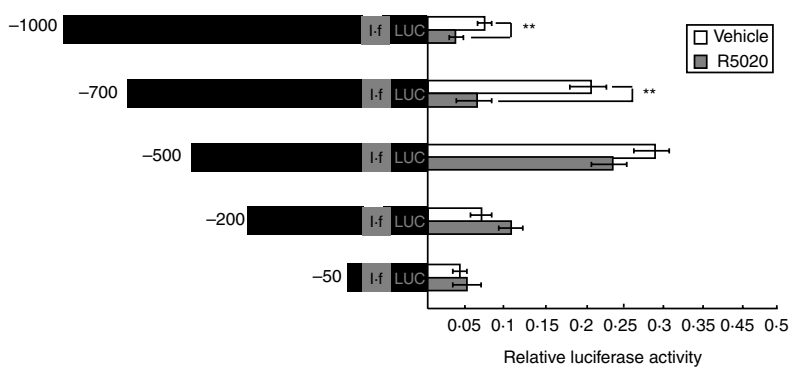

Figure 4 Cis-regulatory elements within the nt $-1000 /-500$ region of aromatase promoter I.f are essential for R5020dependent suppression of aromatase expression in N42 hypothalamic neurons. Serial deletion analysis was performed to localize the R5020-responsive regions of aromatase promoter I.f. The promoter I.f-luciferase reporter constructs were named according to the nucleotide positions of their $5^{\prime}$-termini. All constructs were transiently transfected into N42 hypothalamic neurons. Luciferase assays were performed a minimum of three times in the presence or absence of $10^{-7}$ M R5020. Mean luciferase activity of each construct is given relative to the nt $-1000 /-1$ promoter-luciferase reporter construct. Summary data for three independent experiments are shown. Results are expressed as mean \pm S.E.M. $\left({ }^{\star \star} P<0.01\right.$, paired $t$ test $)$.

aromatase expression and activity in $\mathrm{N} 42$ hypothalamic neurons. Moreover, when treated with R5020 and $\mathrm{E}_{2}$ together, aromatase mRNA expression and enzyme activity were induced in both hypothalamic neuronal lines (Fig. 7A and B). Aromatase enzyme activity in each neuronal line treated with the aromatase enzyme inhibitor LET was undetectable.

\section{Discussion}

Aromatase deficiency in humans disrupts normal gonadotropin regulation and libido (Jones et al. 2006). Likewise, ArKO mice exhibit disrupted reproductive behavior, including defective lordosis (females), low frequency of copulatory behavior (males; Bakker et al. 2003), reduced sexual interest in the opposite sex, and deficiency in pup care (Bakker et al. 2002, 2003, Matsumoto et al. 2003a,b). The gonadotropin secretion profile is also disrupted in ArKO mice, which have increased LH, FSH, testosterone, and prolactin levels, and decreased $\mathrm{E}_{2}$, but unchanged dihydrotestosterone and progesterone (Fisher et al. 1998, Jones et al. 2006).

Aromatase is primarily expressed in gonads and the brain (Simpson 2004a, Bulun et al. 2005). Loss of local $\mathrm{E}_{2}$ synthesis in the brain likely leads to the hormonal and behavioral phenotypes observed in aromatasedeficient humans and mice. In fact, alterations in brain aromatase expression have been directly linked to changes in sexual behavior in birds, rodents, sheep, and humans (Balthazart et al. 2003, Matsumoto et al. 2003a,b, Jones et al. 2006, Perkins \& Roselli 2007).
The role of progesterone in females appears similar in a variety of species, particularly for maternal and reproductive behavior. However, progesterone is capable of protecting females from the masculinizing and defeminizing effects of testosterone (Sodersten \& Hansen 1977, Hansen \& Sodersten 1978). However, progesterone treatment suppresses mounting and intromissive behavior in males (Michael et al. 1968, DeBold et al. 1978, Witt et al. 1995).

Gonadectomy reduces aromatase expression and enzyme activity in the brain in parallel with a recession in gender-specific sexual behavior of both sexes (Jakab et al. 1993, Iivonen et al. 2006). However, treatment of gonadectomized animals with progesterone markedly restores female-specific but not male-specific sexual behavior (Sodersten \& Hansen 1977, Hansen \& Sodersten 1978, Witt et al. 1995). Moreover, treatments of intact animals with the progesterone antagonist, RU486, or antisense oligonucleotides to Pgr increased the number of mounts and intromissions in males but

A

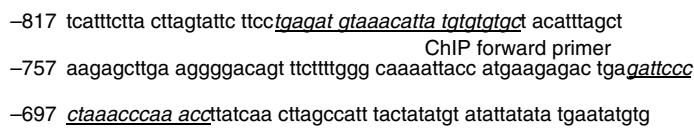

B

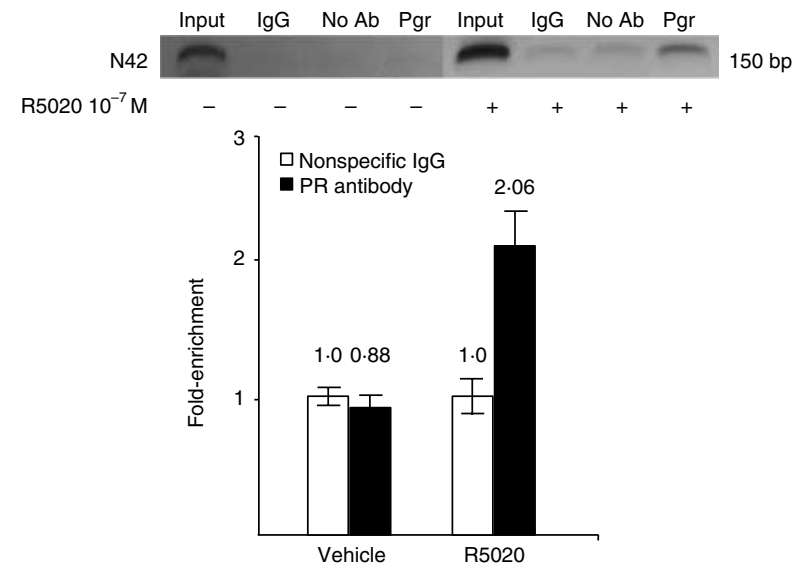

Figure 5 ChIP analysis reveals Pgr recruitment to aromatase promoter I.f in N42 hypothalamic neurons. We performed ChIP assays using $\mathrm{N} 42$ hypothalamic neuron extracts treated with vehicle or $10^{-7} \mathrm{M} \mathrm{R5020}$ for $6 \mathrm{~h}$ employing different sets of primers; the most consistent recruitment was observed with the primers (underlined) in (A). Sonicated cell supernatant was used as input DNA (positive control). Pre-cleared chromatin was used for immunoprecipitation reactions with a rabbit polyclonal antibody directed against human PGR and normal rabbit lgG. The images in (B) are from one of the five independently performed experiments. The bars represent densitometric measurements of the ratio of enrichment of DNA precipitated using an antibody against Pgr versus nonspecific IgG. The bars were generated from repeated experiments. 


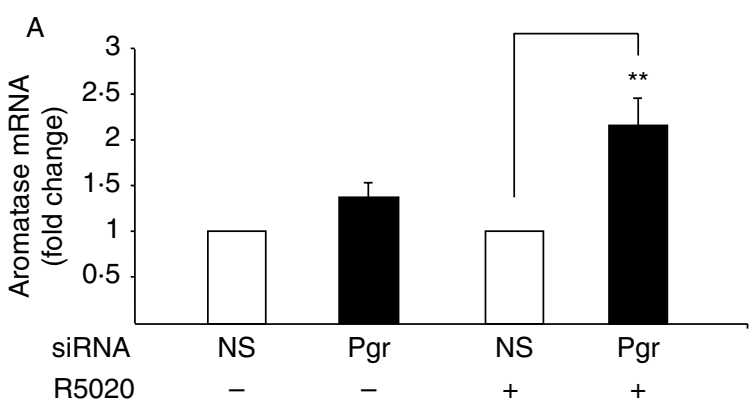

B

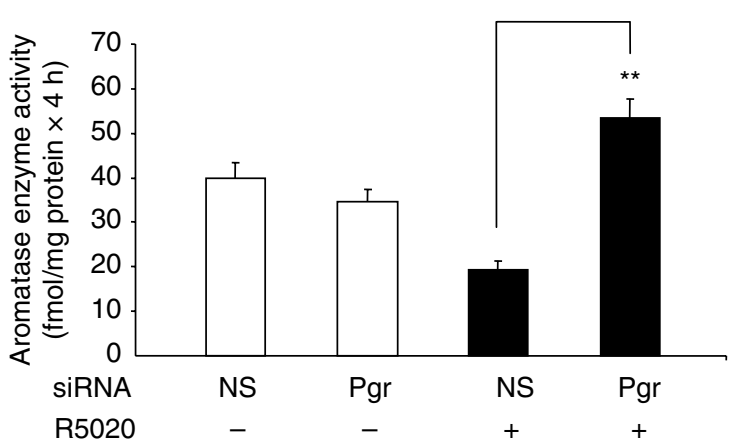

$\mathrm{C}$

D
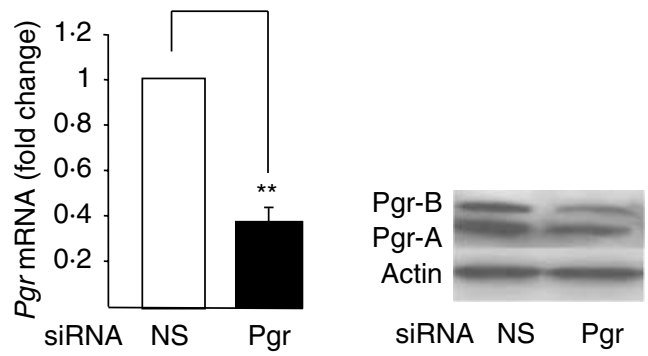

$118 \mathrm{kDa}$ $90 \mathrm{kDa}$ $42 \mathrm{kDa}$

Figure 6 Pgr mediates R5020-dependent suppression of aromatase mRNA expression in N42 hypothalamic neurons. N42 hypothalamic neurons were transfected with Pgr siRNA or with non-specific siRNA as a negative control (NS) and cultured for an additional $48 \mathrm{~h}$. (A) Aromatase mRNA levels were analyzed by real-time RT-PCR in the presence or absence of R5020 $\left(10^{-7} \mathrm{M}, 6 \mathrm{~h}\right)$. Aromatase mRNA levels were normalized to Gapdh mRNA levels. The results are expressed as mean \pm S.E.M. from three independent experiments ( ${ }^{\star \star} P<0 \cdot 01$, ANOVA).

(B) Aromatase activity assays were performed in the presence or absence of R5020 (10 $\left.{ }^{-7} \mathrm{M}, 6 \mathrm{~h}\right)$. The results are expressed as mean \pm S.E.M. from three independent experiments $\left({ }^{\star \star} P<0.01\right.$, ANOVA). Aromatase enzyme activity in N42 neuronal line treated with the aromatase enzyme inhibitor letrozole was undetectable (data not shown). (C) Real-time RT-PCR and (D) immunoblotting were performed to measure Pgr mRNA and protein levels respectively. Actin was used as a loading control. The immunoblot represents one of the three independently performed experiments. Real-time RT-PCR results are expressed as mean \pm s.E.M. from three independent experiments $\left({ }^{\star \star} P<0 \cdot 01\right.$, ANOVA) and Gapdh was used as a loading control. Representative results from three independent experiments are shown. decreased the frequency of lordosis in females (Pollio et al. 1993, Mani et al. 1994). Therefore, the actions of progesterone are necessary for the proceptive components of female sexual behavior, although the mechanism of progesterone action is not fully understood.

The reproductive phenotypes manifested in ArKO male mice are opposite to those observed in progesterone receptor knockout (PRKO) male mice, in which most measures of male sexual behavior are enhanced, suggesting that aromatase and Pgr are important in mediating opposite aspects of reproductive behavior controlled by the brain, in particular, by the hypothalamus in males (Matsumoto et al. 2003a, Schneider et al. 2005). However, PRKO female mice are sterile with impaired maternal and reproductive behavior and neuroendocrine and gonadotropin regulation, suggesting a prominent role of $\mathrm{Pgr}$ in feminization rather than masculinization process (Conneely et al. 2001).

Taken together, the roles that are attributed to progesterone in gender-specific sexual behavior mostly favors the feminization process both in males and in females, which is in contrast to what has been observed in male mice with inactivated Esr1 or Cyp19a1 (aromatase), suggesting that Pgr and Esr1/aromatase may regulate opposite aspects of reproductive behavior, particularly in males.

In the hypothalamic tissue of neonatal males, progesterone does not affect the accumulation of testosterone, but completely prevents the formation of $\mathrm{E}_{2}$, suggesting that progesterone may inhibit hypothalamic aromatase expression and/or enzyme activity in the neonatal brain (Rhoda et al. 1987). Consistent with these findings, we found that progesterone treatment suppressed aromatase mRNA expression and enzyme activity (Fig. 2).

The varying intracellular concentration of progesterone and possible alterations in the composition of the transcriptional complex at promoter I.f over time may explain the mechanism of biphasic response observed in this study. These considerations will be investigated as future directions.

Progesterone can also inhibit Esr1 expression and $\mathrm{E}_{2}$ can induce the expression of both Pgr isoforms (Evans \& Leavitt 1980, Smanik et al. 1983). We observed a slight decrease in Esr1, but not Esr2 (also known as ER $\beta$ ) expression levels upon R5020 treatment in hypothalamic cells (data not shown). This may represent an alternative mechanism whereby progesterone regulates aromatase expression in hypothalamic neurons.

In parallel, it is known that $\mathrm{E}_{2}$ induces Pgr expression and inhibition of aromatase suppresses Pgr expression in the brain, suggesting a negative feedback mechanism between progesterone and aromatase (Ing \& Tornesi 

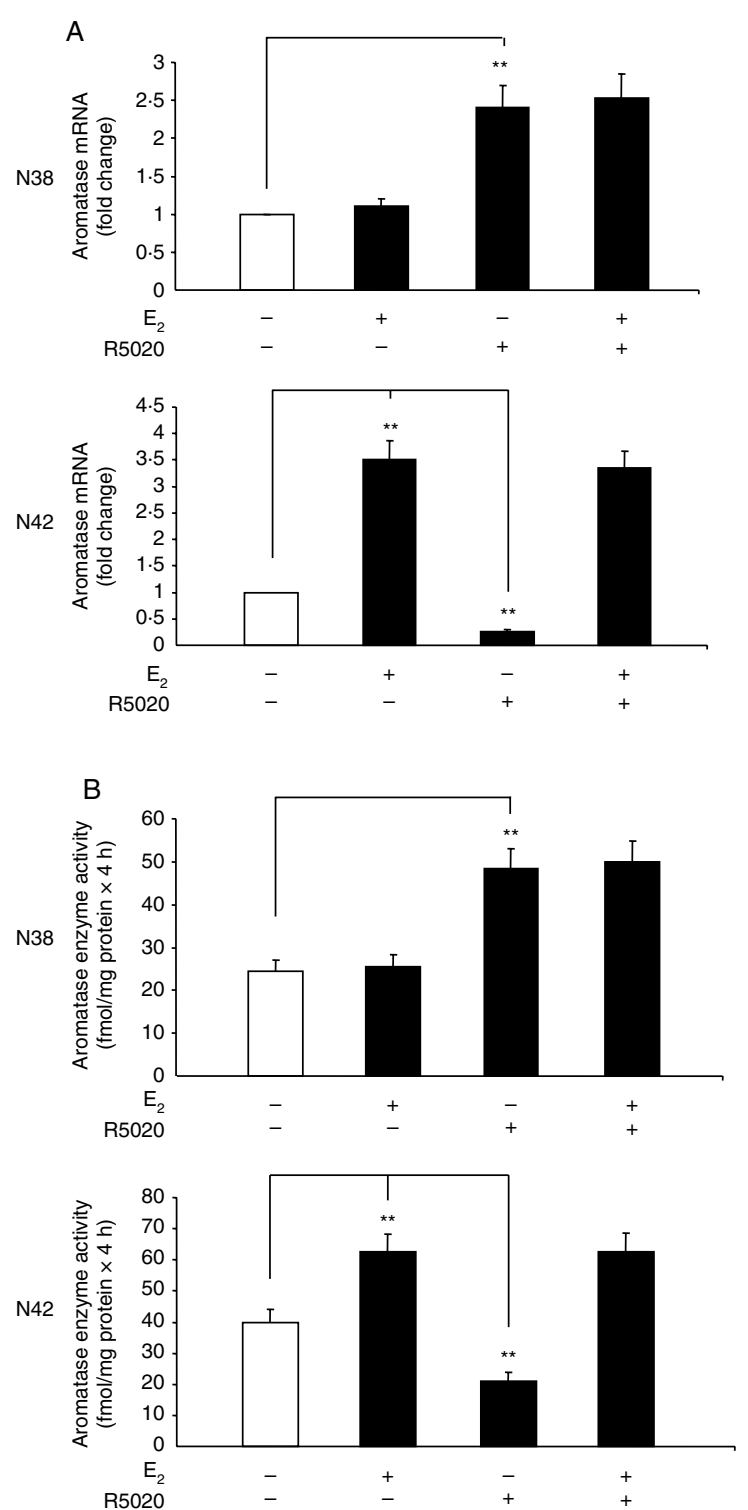

Figure 7 Combinatory effects of $E_{2}$ and $R 5020$ on aromatase are cell-type specific. (A) Real-time RT-PCR was performed to measure aromatase mRNA expression after $6 \mathrm{~h}$ of R5020 $\left(10^{-7} \mathrm{M}\right)$ or $\mathrm{E}_{2}\left(10^{-7} \mathrm{M}\right)$ or $\mathrm{R} 5020\left(10^{-7} \mathrm{M}\right)+\mathrm{E}_{2}\left(10^{-7} \mathrm{M}\right)$ treatment in both $\mathrm{N} 38$ and $\mathrm{N} 42$ hypothalamic neurons. Aromatase mRNA levels were normalized to Gapdh mRNA levels. Results are expressed as mean \pm S.E.M. from three independent experiments ( ${ }^{* \star} P<0 \cdot 01$, paired $t$ test). (B) Aromatase activity assays were performed in both N38 and N42 hypothalamic neurons following the described treatment procedure in $(A)$. The results are expressed as mean \pm S.E.M. from three independent experiments $\left({ }^{\star *} P<0 \cdot 01\right.$, paired $t$ test).

1997, Prange-Kiel et al. 2001). Consistent with this hypothesis, we found that Pgr interacts with the aromatase I.f promoter in the presence but not in the absence of R5020, with the highest intensity at the nt $-800 /-600$ region of promoter I.f (Fig. 4).
The perinatal rodent brain expresses all the enzymes required for the de novo synthesis of progesterone from cholesterol, potentially producing locally high concentrations of this steroid. $\mathrm{E}_{2}$ concentration in certain brain areas, such as the hypothalamus, preoptic area, and the hippocampus, is higher than the plasma $\mathrm{E}_{2}$ levels (Hojo et al. 2004, Rune et al. 2006). Even though the total amount of $\mathrm{E}_{2}$ synthesized by these brain sites seems to be low, the achieved local tissue concentrations are probably quite high and exert significant biologic influence locally (Simpson et al. 1999, PrangeKiel et al. 2003). The same phenomenon could also be true for progesterone adding another layer of complexity to the phenomenally complex mechanism involving estrogen and progesterone production and action in various regions.

Various studies investigating the effects of progesterone on reproductive behavior used supraphysiological levels of progesterone that would greatly exceed its levels accounted for by ovarian secretion (Erpino 1975, Connolly \& Resko 1989). However, the endogenous levels of progesterone can be locally regulated in specific tissues or regions of the brain (Le Goascogne et al. 2000, Tagawa et al. 2006). In our experiments, aromatase regulation by $10^{-7} \mathrm{M}$ R5020, which may represent the cellular progesterone concentration in a particular brain region, cannot be generalized to the effects of this steroid to the entire brain tissue. As a further twist, both the Pgr and the Esr1 levels in N42 neurons are higher than those in N38 hypothalamic neurons, which are possibly accounted for differential responsiveness of these cells to progesterone. Differential responsiveness of N42 and N38 cells to R5020 with respect to aromatase expression was a function of Pgr levels and consistent across various experiments because knockdown of Pgr in N42 cells converted an inhibitory response to a stimulatory one (Figs 1, 6 and 7). We speculate that, in vivo, the varying levels of Pgr and Esr1 in specific brain cells would be key determinants of progesterone responsiveness.

The developmental and tissue-, region-, and neuronspecific expression of aromatase in the brain has been reported to be transcriptionally regulated through promoter I.f (Honda et al. 1999, Nausch et al. 2007). There are several potential cis-regulatory elements, which may be important for promoter regulation, residing in the $5^{\prime}$-flanking region of promoter I.f including PRE half sites. In our experiments, R5020 significantly suppressed luciferase activity of the nt $-1000 /-1$ and nt $-700 /-1$ promoter-reporter constructs but not other promoter-reporter luciferase constructs in N42 hypothalamic neurons (Fig. 4). We did not observe suppression of luciferase activity of the promoter-luciferase reporter constructs on R5020 treatment in N38 hypothalamic neurons, due possibly 
to higher Pgr expression in N42 hypothalamic neurons compared with N38 hypothalamic neurons.

Aromatase in the fetal brain is also proposed to be regulated via sex hormones, specifically $\mathrm{E}_{2}$ that has both stimulatory and inhibitory effects on aromatase expression and enzyme activity in the brain (Iivonen et al. 2006). Our group has recently showed that Esr1 mediates $\mathrm{E}_{2}$ actions on aromatase expression and enzyme activity through its brain-specific promoter in embryonic hypothalamic neuronal cell lines (Yilmaz et al. 2009). Progesterone has also been implicated in the regulation aromatase expression and enzyme activity (Rhoda et al. 1987, Ing \& Tornesi 1997, Prange-Kiel et al. 2001, Trainor et al. 2003). Interestingly, Brock et al. (2010) has recently showed that Pgr and aromatase expression is conversely related in the mouse hypothalamus, suggesting a feedback loop between progesterone and aromatase. In this study, we showed that progesterone enhances recruitment of Pgr to specific regions of the promoter I.f of Cyp19a1 and regulates aromatase expression in hypothalamic neurons.

We identified several progesterone response elements (half sites) in both nt $-1000 /-700$ and nt $-700 /-500$, with nt $-800 /-600$ having the highest intensity of Pgr recruitment sites as assessed by ChIP. Furthermore, the effect of $\mathrm{E}_{2}$ and progesterone on aromatase mRNA expression and enzyme activity is Esr1/Pgr expression dependent (Fig. 7), with higher receptor expression favoring induction of aromatase on $\mathrm{E}_{2}$ treatment and suppression on R5020 treatment, and with lower receptor expression favoring induction on R5020 treatment and no alteration on $\mathrm{E}_{2}$ treatment.

Taken together, we demonstrated the mechanism of a Pgr action in mediating progesterone-dependent regulation of aromatase expression and enzyme activity in hypothalamic neurons in a time-, concentration-, and Esr1/Pgr expression-dependent manner. Our future directions include verification of these findings using in vivo models. We also plan to further investigate the in vitro and in vivo effects of other hormones and metabolites on aromatase expression and activity to elucidate the molecular mechanisms mediating local $\mathrm{E}_{2}$ synthesis in the hypothalamus and other regions of the brain.

\section{Declaration of interest}

The authors declare that there is no conflict of interest that could be perceived as prejudicing the impartiality of the research reported.

\section{Funding}

This work was funded, in part, by grants from the NIH (HD38691, HD57877) and Friends of Prentice.

\section{Author contribution statement}

Dr M B Y performed the key experiments and wrote the draft manuscript. Dr H Z and C B performed other important experiments. Drs AW and S E B significantly contributed to the experimental design.

\section{Acknowledgements}

We acknowledge Dr Zhihong Lin and Scott Reierstad for their technical contributions to the ChIP experiments.

\section{References}

Abdelgadir SE, Resko JA, Ojeda SR, Lephart ED, McPhaul MJ \& Roselli CE 1994 Androgens regulate aromatase cytochrome P450 messenger ribonucleic acid in rat brain. Endocrinology 135 395-401. (doi:10.1210/en.135.1.395)

Bakker J, Honda S, Harada N \& Balthazart J 2002 The aromatase knock-out mouse provides new evidence that estradiol is required during development in the female for the expression of sociosexual behaviors in adulthood. Journal of Neuroscience 22 9104-9112.

Bakker J, Honda S, Harada N \& Balthazart J 2003 The aromatase knockout (ArKO) mouse provides new evidence that estrogens are required for the development of the female brain. Annals of the New York Academy of Sciences 1007 251-262. (doi:10.1196/annals.1286. 024)

Bakker J, Baillien M, Honda S, Harada N \& Balthazart J $2004 a$ Relationships between aromatase activity in the brain and gonads and behavioural deficits in homozygous and heterozygous aromatase knockout mice. Journal of Neuroendocrinology 16 483-490. (doi:10.1111/j.1365-2826.2004.01191.x)

Bakker J, Honda S, Harada N \& Balthazart J 2004b Restoration of male sexual behavior by adult exogenous estrogens in male aromatase knockout mice. Hormones and Behavior 46 1-10. (doi:10.1016/ j.yhbeh.2004.02.003)

Balthazart J, Baillien M \& Ball GF 2001 Phosphorylation processes mediate rapid changes of brain aromatase activity. Journal of Steroid Biochemistry and Molecular Biology 79 261-277. (doi:10.1016/S09600760(01)00143-1)

Balthazart J, Baillien M, Charlier TD, Cornil CA \& Ball GF 2003 Multiple mechanisms control brain aromatase activity at the genomic and non-genomic level. Journal of Steroid Biochemistry and Molecular Biology 86 367-379. (doi:10.1016/S0960-0760(03) 00346-7)

Brock O, Douhard Q, Baum MJ \& Bakker J 2010 Reduced prepubertal expression of progesterone receptor in the hypothalamus of female aromatase knockout mice. Endocrinology 151 1814-1821. (doi:10.1210/en.2009-1379)

Bulun SE, Lin Z, Imir G, Amin S, Demura M, Yilmaz B, Martin R, Utsunomiya H, Thung S, Gurates B et al. 2005 Regulation of aromatase expression in estrogen-responsive breast and uterine disease: from bench to treatment. Pharmacological Reviews $\mathbf{5 7}$ 359-383. (doi:10.1124/pr.57.3.6)

Chow JD, Simpson ER \& Boon WC 2009 Alternative 5 '-untranslated first exons of the mouse Cyp19A1 (aromatase) gene. Journal of Steroid Biochemistry and Molecular Biology 115 115-125. (doi:10.1016/ j.jsbmb.2009.03.010)

Conneely OM, Mulac-Jericevic B, Lydon JP \& De Mayo FJ 2001 Reproductive functions of the progesterone receptor isoforms: lessons from knock-out mice. Molecular and Cellular Endocrinology 179 97-103. (doi:10.1016/S0303-7207(01)00465-8)

Connolly PB \& Resko JA 1989 Progestins affect reproductive behavior and androgen receptor dynamics in male guinea pig brain. Brain Research 503 312-316. (doi:10.1016/0006-8993(89)91681-8) 
DeBold JF, Morris JL \& Clemens LG 1978 The inhibitory actions of progesterone: effects on male and female sexual behavior of the hamster. Hormones and Behavior 11 28-41. (doi:10.1016/0018506X(78)90056-9)

Erpino MJ 1975 Androgen-induced aggression in neonatally androgenized female mice: inhibition by progesterone. Hormones and Behavior 6 149-157. (doi:10.1016/0018-506X(75)90030-6)

Evans RW \& Leavitt WW 1980 Progesterone inhibition of uterine nuclear estrogen receptor: dependence on RNA and protein synthesis. PNAS 77 5856-5860. (doi:10.1073/pnas.77.10.5856)

Fisher CR, Graves KH, Parlow AF \& Simpson ER 1998 Characterization of mice deficient in aromatase (ArKO) because of targeted disruption of the cyp19 gene. PNAS 95 6965-6970. (doi:10.1073/ pnas.95.12.6965)

Fortune JE \& Vincent SE 1983 Progesterone inhibits the induction of aromatase activity in rat granulosa cells in vitro. Biology of Reproduction 28 1078-1089. (doi:10.1095/biolreprod28.5.1078)

Golovine K, Schwerin M \& Vanselow J 2003 Three different promoters control expression of the aromatase cytochrome p450 gene (cyp19) in mouse gonads and brain. Biology of Reproduction 68 978-984. (doi:10.1095/biolreprod.102.008037)

Hansen S \& Sodersten P 1978 Effects of subcutaneous implants of progesterone on the induction and duration of sexual receptivity in ovariectomized rats. Journal of Endocrinology 77 373-379. (doi:10. 1677/joe.0.0770373)

Hojo Y, Hattori TA, Enami T, Furukawa A, Suzuki K, Ishii HT, Mukai H, Morrison JH, Janssen WG, Kominami S et al. 2004 Adult male rat hippocampus synthesizes estradiol from pregnenolone by cytochromes $\mathrm{P} 45017$ alpha and $\mathrm{P} 450$ aromatase localized in neurons. PNAS 101 865-870. (doi:10.1073/pnas. 2630225100)

Honda S, Harada N \& Takagi Y 1996 The alternative exons 1 of the mouse aromatase cytochrome P-450 gene. Biochemica et Biophysica Acta 1305 145-150. (doi:10.1016/0167-4781(95)00200-6)

Honda S, Harada N, Abe-Dohmae S \& Takagi Y 1999 Identification of cis-acting elements in the proximal promoter region for brainspecific exon 1 of the mouse aromatase gene. Brain Research. Molecular Brain Research 66 122-132. (doi:10.1016/S0169328X(99)00017-0)

Iivonen S, Heikkinen T, Puolivali J, Helisalmi S, Hiltunen M, Soininen H \& Tanila H 2006 Effects of estradiol on spatial learning, hippocampal cytochrome P450 19, and estrogen alpha and beta mRNA levels in ovariectomized female mice. Neuroscience 137 1143-1152. (doi:10.1016/j.neuroscience.2005. $10.023)$

Ing NH \& Tornesi MB 1997 Estradiol up-regulates estrogen receptor and progesterone receptor gene expression in specific ovine uterine cells. Biology of Reproduction 56 1205-1215. (doi:10.1095/ biolreprod56.5.1205)

Jakab RL, Horvath TL, Leranth C, Harada N \& Naftolin F 1993 Aromatase immunoreactivity in the rat brain: gonadectomysensitive hypothalamic neurons and an unresponsive "limbic ring" of the lateral septum-bed nucleus-amygdala complex. Journal of Steroid Biochemistry and Molecular Biology 44 481-498. (doi:10.1016/ 0960-0760 (93)90253-S)

Jones ME, Boon WC, Proietto J \& Simpson ER 2006 Of mice and men: the evolving phenotype of aromatase deficiency. Trends in Endocrinology and Metabolism 17 55-64. (doi:10.1016/j.tem.2006. 01.004)

Keefe DL 2002 Sex hormones and neural mechanisms. Archives of Sexual Behavior 31 401-403. (doi:10.1023/A:1019883923346)

Lavaque E, Mayen A, Azcoitia I, Tena-Sempere M \& Garcia-Segura LM 2006 Sex differences, developmental changes, response to injury and cAMP regulation of the mRNA levels of steroidogenic acute regulatory protein, cytochrome p450scc, and aromatase in the olivocerebellar system. Journal of Neurobiology 66 308-318. (doi:10.1002/neu.20221)
Le Goascogne C, Eychenne B, Tonon MC, Lachapelle F, Baumann N \& Robel P 2000 Neurosteroid progesterone is up-regulated in the brain of jimpy and shiverer mice. Glia 29 14-24. (doi:10.1002/ (SICI) 1098-1136(20000101) 29:1 < 14::AID-GLIA2>3.0.CO;2-N)

Lephart ED 1996 A review of brain aromatase cytochrome P450. Brain Research. Brain Research Reviews 22 1-26. (doi:10.1016/01650173(96)00002-1)

Lephart ED 1997 Molecular aspects of brain aromatase cytochrome P450. Journal of Steroid Biochemistry and Molecular Biology 61 375-380. (doi:10.1016/S0960-0760(97)80035-0)

Lephart ED, Butler PC, Mills RH, Jacobson NA, Ladle DR \& Bloch GJ 1998 Effects of testosterone and progesterone on brain 5alphareductase and aromatase in Long-Evans males and comparison of aromatase in Long-Evans vs. Sprague-Dawley rats. Brain Research 789 327-330. (doi:10.1016/S0006-8993(97)01553-9)

Levine JE, Chappell PE, Schneider JS, Sleiter NC \& Szabo M 2001 Progesterone receptors as neuroendocrine integrators. Frontiers in Neuroendocrinology 22 69-106. (doi:10.1006/frne.2001.0210)

Mani SK, Blaustein JD, Allen JM, Law SW, O’Malley BW \& Clark JH 1994 Inhibition of rat sexual behavior by antisense oligonucleotides to the progesterone receptor. Endocrinology 135 1409-1414. (doi:10. $1210 /$ en.135.4.1409)

Matsumoto T, Honda S \& Harada N 2003a Alteration in sex-specific behaviors in male mice lacking the aromatase gene. Neuroendocrinology 77 416-424. (doi:10.1159/000071313)

Matsumoto T, Honda S \& Harada N $2003 b$ Neurological effects of aromatase deficiency in the mouse. Journal of Steroid Biochemistry and Molecular Biology 86 357-365. (doi:10.1016/S0960-0760(03) 00345-5)

Michael RP, Saayman GS \& Zumpe D 1968 The suppression of mounting behaviour and ejaculation in male rhesus monkeys (Macaca mulatta) by administration of progesterone to their female partners. Journal of Endocrinology 41 421-431. (doi:10.1677/joe.0. 0410421)

Nausch N, Manteuffel G \& Vanselow J 2007 0.2 kb promoter sequence of the murine Cyp19 gene target beta-galactosidase expression to specific brain areas of transgenic mice. Journal of Steroid Biochemistry and Molecular Biology 103 119-128. (doi:10.1016/j.jsbmb.2006. 08.007)

Negri-Cesi P, Colciago A, Motta M, Martini L \& Celotti F 2001 Aromatase expression and activity in male and female cultured rat hypothalamic neurons: effect of androgens. Molecular and Cellular Endocrinology 178 1-10. (doi:10.1016/S0303-7207(01)00442-7)

Perkins A \& Roselli CE 2007 The ram as a model for behavioral neuroendocrinology. Hormones and Behavior 52 70-77. (doi:10.1016/j.yhbeh.2007.03.016)

Peterson RS, Yarram L, Schlinger BA \& Saldanha CJ 2005 Aromatase is pre-synaptic and sexually dimorphic in the adult zebra finch brain. Proceedings. Biological Sciences/The Royal Society 272 2089-2096. (doi:10.1098/rspb.2005.3181)

Pluchino N, Luisi M, Lenzi E, Centofanti M, Begliuomini S, Freschi L, Ninni F \& Genazzani AR 2006 Progesterone and progestins: effects on brain, allopregnanolone and beta-endorphin. Journal of Steroid Biochemistry and Molecular Biology 102 205-213. (doi:10.1016/j. jsbmb.2006.09.023)

Pollio G, Xue P, Zanisi M, Nicolin A \& Maggi A 1993 Antisense oligonucleotide blocks progesterone-induced lordosis behavior in ovariectomized rats. Brain Research. Molecular Brain Research 19 135-139. (doi:10.1016/0169-328X(93)90158-L)

Prange-Kiel J, Rune GM, Zwirner M, Wallwiener D \& Kiesel L 2001 Regulation of estrogen receptor alpha and progesterone receptor (isoform A and B) expression in cultured human endometrial cells. Experimental and Clinical Endocrinology and Diabetes 109 231-237. (doi:10.1055/s-2001-15111)

Prange-Kiel J, Wehrenberg U, Jarry H \& Rune GM 2003 Para/autocrine regulation of estrogen receptors in hippocampal neurons. Hippocampus 13 226-234. (doi:10.1002/hipo.10075) 
Rhoda J, Valens M, Edwards DA \& Roffi J 1987 Effect of progesterone on the testosterone and estradiol levels in the hypothalamus of neonatal rats. Biology of the Neonate 51 255-259. (doi:10.1159/ 000242661)

Roselli CE, Abdelgadir SE \& Resko JA 1997 Regulation of aromatase gene expression in the adult rat brain. Brain Research Bulletin 44 351-357. (doi:10.1016/S0361-9230(97)00214-1)

Rune GM, Lohse C, Prange-Kiel J, Fester L \& Frotscher M 2006 Synaptic plasticity in the hippocampus: effects of estrogen from the gonads or hippocampus? Neurochemical Research 31 145-155. (doi:10.1007/s11064-005-9004-8)

Schneider JS, Burgess C, Sleiter NC, DonCarlos LL, Lydon JP, O'Malley B \& Levine JE 2005 Enhanced sexual behaviors and androgen receptor immunoreactivity in the male progesterone receptor knockout mouse. Endocrinology 146 4340-4348. (doi:10.1210/en.2005-0490)

Sharma TP, Blache D, Roselli CE \& Martin GB 2004 Distribution of aromatase activity in brain and peripheral tissues of male sheep: effect of nutrition. Reproduction, Fertility, and Development 16 709-715. (doi:10.1071/RD04018)

Shozu M, Sebastian S, Takayama K, Hsu WT, Schultz RA, Neely K, Bryant M \& Bulun SE 2003 Estrogen excess associated with novel gain-of-function mutations affecting the aromatase gene. New England Journal of Medicine 348 1855-1865. (doi:10.1056/ NEJMoa021559)

Simpson ER 2004a Aromatase: biologic relevance of tissue-specific expression. Seminars in Reproductive Medicine 22 11-23. (doi:10. $1055 / \mathrm{s}-2004-823023)$

Simpson ER 2004b Models of aromatase insufficiency. Seminars in Reproductive Medicine 22 25-30. (doi:10.1055/s-2004-823024)

Simpson ER \& Davis SR 2001 Minireview: aromatase and the regulation of estrogen biosynthesis - some new perspectives. Endocrinology 142 4589-4594. (doi:10.1210/en.142.11.4589)

Simpson E, Rubin G, Clyne C, Robertson K, O’Donnell L, Davis S \& Jones M 1999 Local estrogen biosynthesis in males and females. Endocrine-Related Cancer 6 131-137. (doi:10.1677/erc.0.0060131)

Smanik EJ, Young HK, Muldoon TG \& Mahesh VB 1983 Analysis of the effect of progesterone in vivo on estrogen receptor distribution in the rat anterior pituitary and hypothalamus. Endocrinology 113 15-22. (doi:10.1210/endo-113-1-15)
Sodersten P \& Hansen S 1977 Effects of oestradiol and progesterone on the induction and duration of sexual receptivity in cyclic female rats. Journal of Endocrinology 74 477-485. (doi:10.1677/joe.0. 0740477)

Tagawa N, Sugimoto Y, Yamada J \& Kobayashi Y 2006 Strain differences of neurosteroid levels in mouse brain. Steroids 71 776-784. (doi:10. 1016/j.steroids.2006.05.008)

Trainor BC, Bird IM, Alday NA, Schlinger BA \& Marler CA 2003 Variation in aromatase activity in the medial preoptic area and plasma progesterone is associated with the onset of paternal behavior. Neuroendocrinology 78 36-44. (doi:10.1159/000071704)

Voigt C, Ball GF \& Balthazart J 2007 Neuroanatomical specificity of sex differences in expression of aromatase mRNA in the quail brain. Journal of Chemical Neuroanatomy 33 75-86. (doi:10.1016/j.jchemneu.2006.12.004)

Wagner CK 2006 The many faces of progesterone: a role in adult and developing male brain. Frontiers in Neuroendocrinology 27 340-359. (doi:10.1016/j.yfrne.2006.07.003)

Witt DM, Young LJ \& Crews D 1995 Progesterone modulation of androgen-dependent sexual behavior in male rats. Physiology and Behavior 57 307-313. (doi:10.1016/0031-9384(94)00247-3)

Yilmaz MB, Wolfe A, Cheng YH, Glidewell-Kenney C, Jameson JL \& Bulun SE 2009 Aromatase promoter I.f is regulated by estrogen receptor alpha (ESR1) in mouse hypothalamic neuronal cell lines. Biology of Reproduction 81 956-965. (doi:10.1095/biolreprod.109. 077206)

Zhao C, Fujinaga R, Tanaka M, Yanai A, Nakahama K \& Shinoda K 2007 Region-specific expression and sex-steroidal regulation on aromatase and its mRNA in the male rat brain: immunohistochemical and in situ hybridization analyses. Journal of Comparative Neurology 500 557-573. (doi:10.1002/cne.21193)

Zhao H, Innes J, Brooks DC, Reierstad S, Yilmaz MB, Lin Z \& Bulun SE 2009 A novel promoter controls Cyp19al gene expression in mouse adipose tissue. Reproductive Biology and Endocrinology 24 7-37. (doi:10.1186/1477-7827-7-37)

Received in final form 2 May 2011

Accepted 27 May 2011

Made available online as an Accepted Preprint 31 May 2011 